ISSN 0258-7122

Bangladesh J. Agril. Res. 40(3): 501-506, September 2015

\title{
RESPONSE OF LENTIL TO BIO AND CHEMICAL FERTILIZERS AT FARMER'S FIELD
}

\author{
M. A. H. BHUIYAN ${ }^{1}$, M. S. ISLAM ${ }^{2}$ AND M. S. AHMED ${ }^{3}$
}

\begin{abstract}
Field trials were carried out at the Farming System Research \& Development site, Hatgavindapur, Faridpur, On-Farm Research Division of Bangladesh Agricultural Research Institute during rabi seasons of 2006-2007 and 2007-2008 with the objectives to evaluate the response of lentil to Rhizobium biofertilizer and to reduce the use of $\mathrm{N}$-fertilizer under farmer's field condition. The experiment was laid out in Randomized Complete Block Design (RCBD) with four replications. Unit plot size was $4 \mathrm{~m} \times 5 \mathrm{~m}$. Four fertilizer treatments viz. $\mathrm{T}_{1}$ : 24-22-42-20-5 kg N-P-K-S-Zn ha ${ }^{-1}, \mathrm{~T}_{2}$ : 50-22-42-20-5 kg N-P-K-S-Zn ha ${ }^{-1}, \mathrm{~T}_{3}$ : 0-22-42-20-5 kg N- P-K-S-Zn ha ${ }^{-1}+$ Rhizobium Inoculum and $\mathrm{T}_{4}$ : Farmer's practices were studied. Farmer's practice was 25-18-21-0-0 kg N-P-K-S-Zn ha ${ }^{-1}$. BARI Masur-4 and peat based rhizobial inoculum (strain BARI RLc-102) @ 1.5 $\mathrm{kg} \mathrm{ha}^{-1}$ were used. Result revealed that application of Rhizobium biofertilizer along with PKSZn chemical fertilizers produced the highest nodule number (11.62 plant $^{-1}$ ) and nodule weight (11.94 mg plant ${ }^{-1}$ ), and the seed yield $1.44 \mathrm{t}$ $\mathrm{ha}^{-1}$. The seed yield was higher in $\mathrm{T}_{3}$ treatments $\left(\mathrm{N}_{0} \mathrm{P}_{22} \mathrm{~K}_{42} \mathrm{~S}_{20} \mathrm{Zn}_{5}+\right.$ Inoculum $)$ than $\mathrm{T}_{1}\left(\mathrm{~N}_{24} \mathrm{P}_{22} \mathrm{~K}_{42} \mathrm{~S}_{20} \mathrm{Zn}_{5}\right)$ and $\mathrm{T}_{2}\left(\mathrm{~N}_{50} \mathrm{P}_{22} \mathrm{~K}_{42} \mathrm{~S}_{20} \mathrm{Zn}_{5}\right)$ treatments. No variation was observed in seed yield in treatments $T_{1}, T_{2}$ and $T_{3}$ but significantly different from farmer's practice. Farmer's practice showed the lowest yield. Economic analysis revealed that $\mathrm{T}_{3}$ treatment i.e. PKSZn plus Rhizobium inoculum gave the highest 5.36 benefit cost ratio (BCR) followed by $\mathrm{T}_{1} 4.68$ and $\mathrm{T}_{2} 3.61$. It is evident from the experiment that application of biofertilizer can be used as substitute of nitrogenous fertilizer for higher yield of lentil at farmer's field in Faridpur.
\end{abstract}

Keywords: Lentil, biofertilizer, chemical fertilizers, nodulation, yield, benefit cost ratio

\section{Introduction}

Lentil (Lens culinaris L.) occupies the top position in terms of popularity and has been placed second in respect of area and production in Bangladesh (BBS, 2012). It is cultivated during rabi season under rainfed condition. About $80 \%$ of total lentil in the country is grown in greater Faridpur, Kustia, Jessore, Rajshahi and Pabna districts of Bangladesh (BBS, 2012). The yield of lentil is very poor (928 $\left.\mathrm{kg} \mathrm{ha}^{-1}\right)(\mathrm{BBS}, 2012)$. There is a great possibility to increase its production by

${ }^{1}$ Principal Scientific Officer, Soil Science Division, BARI, Joydebpur, Gazipur-1701, Bangladesh; ${ }^{2}$ Principal Scientific Officer, RARS, BARI, Jessore, Bangladesh, ${ }^{3}$ Senior Scientific Officer, OFRD, BARI, Faridpur, Bangladesh 
exploiting better colonization of their root and rhizosphere through Rhizobium, which can also reduce the use of nitrogenous fertilizer as well as protect environment. But there is still lacking of sufficient, effective and resistant Rhizobium strains in soil. Moreover, degradation of Rhizobium occurs regularly. So, collection and screening of new Rhizobium strains and their sub-culturing and testing are necessary. For this reason, few indigenous Rhizobium strains were collected from different AEZs of Bangladesh and were screened, tested at research stations. Their efficiency in crop production is needed to be tested at farmers' level. Response of inoculation depends on soil type, cultivars and effectiveness of Rhizobium strains and its competitive ability with native Rhizobium (Dube, 1976; Khanam et al., 1993). Khanam et al., (1999) found 46\% higher seed yield in lentil at Meherpur, 30\% higher at Faridpur and 33\% higher at Jessore districts of Bangladesh due to Rhizobium inoculum. They also observed that inoculated plant with chemical fertilizers gave $72 \%, 59 \%$ and $75 \%$ higher yield over farmers' practice at Meherpur, Faridpur and Jessore districts of Bangladesh, respectively. The present study was, therefore, undertaken with the following objectives; i) the response of lentil to Rhizobium biofertilizer along with chemical fertilizers and ii) to evaluate the reduction of the uses of $\mathrm{N}$-fertilizer for lentil cultivation under farmer's field condition.

\section{Material and Method}

Field trials were carried out at the Farming System Research \& Development (FSRD) site, Hatgavindapur of On-Farm Research Division, Bangladesh Agricultural Research Institute in Faridpur district during rabi seasons of 20062007 and 2007-2008 in randomized complete block design having four replications with four treatments. The unit plot size was $4 \mathrm{~m} \times 5 \mathrm{~m}$. The variety was BARI Masur-4 and peat based rhizobial inoculum BARI RLc-102 was used for the experiment. There were four treatments viz. $\mathrm{T}_{1}: 24-22-42-20-5 \mathrm{~kg}$ N-P-KS-Zn ha ${ }^{-1}$ (BARC, 2005), $\mathrm{T}_{2}$ : 50-22-42-20-5 kg N-P-K-S-Zn ha-1 (Recommended by Soil Science Division, BARI), $\mathrm{T}_{3}$ : 0-22-42-20-5 kg N-P-K-S-Zn ha ${ }^{-1}+$ Rhizobium Inoculum and $\mathrm{T}_{4}$ : Farmer's practice was studied. Farmer's practice was 25-18-21-0-0 kg N-P-K-S-Zn ha ${ }^{-1}$. Peat based Rhizobium inoculum was prepared in the Soil Microbiology Laboratory of BARI. The above peat based rhizobial inoculum @ $1.5 \mathrm{~kg} \mathrm{ha}^{-1}$ containing about $10^{8}$ cells g $\mathrm{g}^{-1}$ inoculum was used. Chemical fertilizers i.e. N, P, K, S and Zn were applied in the treatments @ $24 \mathrm{~kg} \mathrm{~N}$ $\mathrm{ha}^{-1}$ in $\mathrm{T}_{1}$ and $50 \mathrm{~kg} \mathrm{~N} \mathrm{ha}^{-1}$ in $\mathrm{T}_{2}$ from urea, $22 \mathrm{~kg} \mathrm{P} \mathrm{ha}^{-1}$ from TSP, $42 \mathrm{~kg} \mathrm{~K} \mathrm{ha}^{-1}$ from MoP, $20 \mathrm{~kg} \mathrm{Sha}^{-1}$ from gypsum and $5 \mathrm{~kg} \mathrm{Zn} \mathrm{ha}^{-1}$ from zinc oxide in $\mathrm{T}_{1}, \mathrm{~T}_{2}$ and $\mathrm{T}_{3}$ treatments but in farmer's practice, 25-18-21-0-0 kg N-P-K-S-Zn ha ${ }^{-1}$ was used. The seeds were sown on 16 November 2006 and 27 November 2007. 


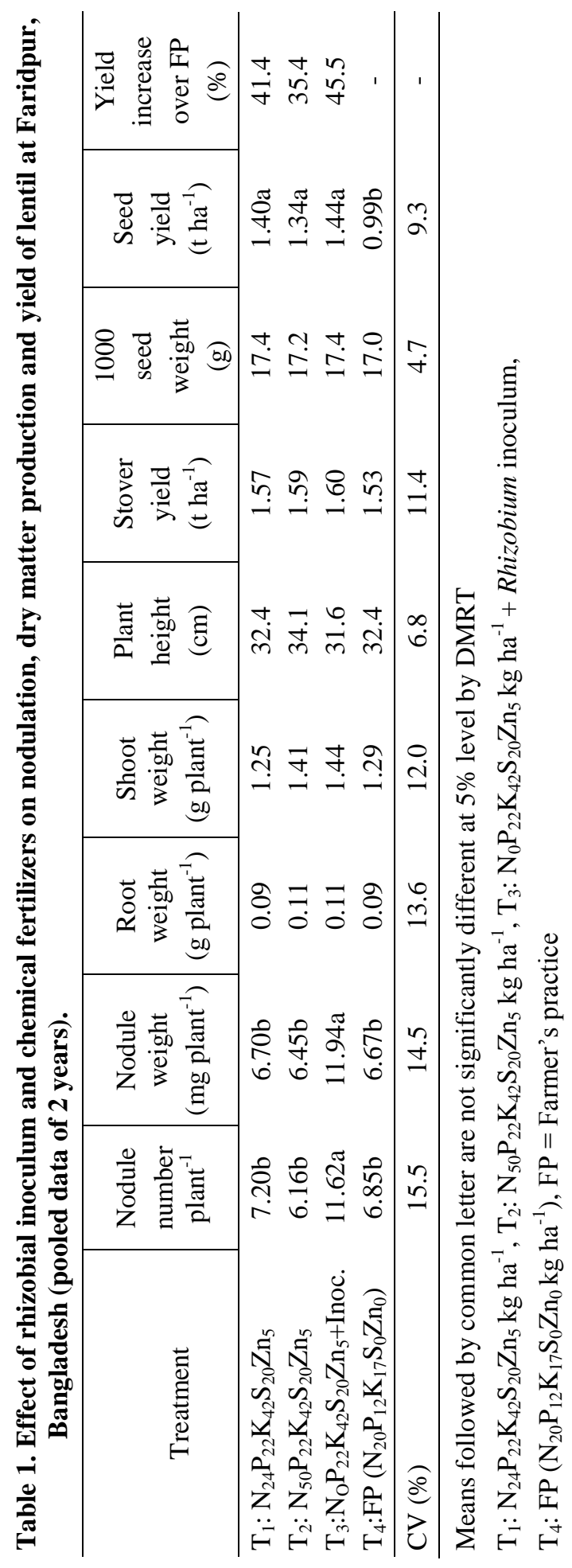


During the experiment, growth and development of plants in the field were carefully observed. Ten plants along with roots were collected at $50 \%$ flowering stage from each unit plot. The dry weight of roots; shoots and nodules including nodule numbers were recorded. The plants were harvested on 07 March for 2007 and 02 March for 2008. Data on plant height, 1000-seed weight, stover yield and seed yield were taken. All data were analyzed statistically.

\section{Results and Discussion}

Effect of Rhizobium inoculation and the application of chemical fertilizers on nodule number $\left(\right.$ plant $\left.^{-1}\right)$, nodule weight $\left(\mathrm{mg} \mathrm{plant}^{-1}\right)$, root weight $\left(\mathrm{g} \mathrm{plant}^{-1}\right)$, shoot weight $\left(\mathrm{g} \mathrm{plant}^{-1}\right)$, plant height $(\mathrm{cm}), 1000$-seed weight $(\mathrm{g})$, stover yield $\left(\mathrm{t} \mathrm{ha}^{-1}\right)$, seed yield $\left(\mathrm{t} \mathrm{ha}^{-1}\right)$ and percent yield increased over farmer's practice have been presented in Table 1.

The highest nodule number (11.62 plant $\left.^{-1}\right)$ and nodule weight (11.94 mg plant $\left.{ }^{-1}\right)$ were recorded in PKSZn + Inoculum treated plot which was significantly higher over other treatments (Table 1). The treatments $T_{1}, T_{2}$ and $T_{4}$ produced identical nodule number and weight. Among the 4 treatments, $\mathrm{T}_{2}$ treatments $\left(\mathrm{N}_{24} \mathrm{P}_{22} \mathrm{~K}_{42} \mathrm{~S}_{20} \mathrm{Zn}_{5}\right)$ produced the lowest nodule number and weight. Khanam et al., (1993) reported higher nodule number (156-245\%) and nodule weight (169$284 \%$ ) due to Rhizobium inoculation in lentil. Khanam et al., (1999) observed that Rhizobium inoculum gave 167\%, 60\% and 136\% higher nodule mass over control at Kustia, Faridpur and Jessore, respectively while Rhizobium inoculum plus chemical fertilizers except $\mathrm{N}$ gave $342 \%, 106 \%$ and $264 \%$ higher nodule mass at Meherpur, Faridpur and Jessore, respectively. Bhuiyan et al., (1996) also found higher nodule number (101\%) at farmer's field of Faridpur, Bangladesh and $110 \%$ at farmer's field of Jessore, Bangladesh, and nodule weight $52 \%$ higher at Faridpur and $81 \%$ higher at farmer's field at Jessore due to Rhizobim inoculation in chickpea. Similar trends were also reported by Bhuiyan et al., (2001) for chickpea at farmers' field of Meherpur and Rajshahi districts of Bangladesh. Root weight, shoot weight, plant height, stover yield and 1000-seed weight were found insignificant, though the highest values were observed in PKSZn + Inoculum treatment. Similar results were reported by Bhuiyan et al., (2001) in chickpea at Rajshahi, Bangladesh. The seed yield was significantly influenced by inoculum. The highest seed yield $1.44 \mathrm{t} \mathrm{ha}^{-1}$ were recorded with the treatment $\mathrm{P}_{22} \mathrm{~K}_{42} \mathrm{~S}_{20} \mathrm{Zn}_{5}+$ Inoculum but identical with $\mathrm{T}_{1}$ and $\mathrm{T}_{2}$ treatments. The seed yield showed higher $1.44 \mathrm{t} \mathrm{ha}^{-1}$ due to higher pods plant ${ }^{-1}$, seeds pod ${ }^{-1}$ and 1000-seed weight. The similar trend was also reported by Khanam et al., (1993). They reported that Rhizobium inoculation gave 64-68\% higher seed yield in lentil. In another study, Khanam et al., (1999) found 46\% higher seed yield in lentil at Meherpur, 30\% at Faridpur and 33\% at Jessore districts of Bangladesh due to Rhizobium inoculum. The lower seed yield was recorded in $\mathrm{T}_{2}$ treatment than $\mathrm{T}_{1}$ which might be due to excess plant growth and less pod setting. The lowest yield was with farmer's practice $\left(0.99 \mathrm{t} \mathrm{ha}^{-1}\right)$. Rhizobium inoculum with 
inorganic fertilizer $T_{3}$, showed better performance against only with inorganic fertilizers $T_{1}$ and $T_{2}$ treatments. The yield was $100 \mathrm{~kg}$ higher than $\mathrm{T}_{2}$ due to application of Rhizobium inoculum. So, Rhizobium inoculum can be used as the substitute of urea for lentil cultivation at Faridpur area. Khanam et al., (1999) also observed that inoculated plant with chemical fertilizers gave 72\%, 59\% and $75 \%$ higher yield over farmers' practice at Meherpur, Faridpur and Jessore districts of Bangladesh, respectively. The results are also an agreement with the findings of Bhuiyan et al., (1998).

\section{Farmers' reaction}

The farmer's of Faridpur district were very encouraged by observing the performance of BARI Masur-4 with rhizobial inoculum.

\section{Economic analysis}

Benefit cost ratio (BCR) analysis for lentil at Faridpur has been presented in Table 2. For BCR only cost of chemical fertilizers and Rhizobium inoculum were considered and other costs remain constant. Economic analysis revealed that $\mathrm{T}_{3}$ treatment i.e. PKSZn with inoculum gave the highest BCR 5.36 at Faridpur. Khanam et al., (1993) found that inoculated treatment with PKSZn fertilizers gave higher benefit cost ratio 6.44-7.68 in lentil. Bhuiyan and Khanam (1996) found BCR 8.71-9.61 by PKSZn + Rhizobium inoculum in chickpea.

Table 2. Benefit cost ratio analysis for lentil at Faridpur (mean of 2 years).

\begin{tabular}{l|c|c|c|c|c|c}
\hline Treatments & $\begin{array}{c}\text { Yield } \\
\left(\mathrm{t} \mathrm{ha}^{-1}\right)\end{array}$ & $\begin{array}{c}\text { Variable } \\
\text { cost } \\
\left(\mathrm{Tk}^{-1} \mathrm{ha}^{-1}\right)\end{array}$ & $\begin{array}{c}\text { Gross } \\
\text { return } \\
\left(\mathrm{Tk}^{-1} \mathrm{ha}^{-1}\right)\end{array}$ & $\begin{array}{c}\text { Net } \\
\text { return } \\
\left(\mathrm{Tk}^{-1}\right)\end{array}$ & $\begin{array}{c}\text { Net return } \\
\text { over } \\
\text { farmer's } \\
\text { practice }(\mathrm{Tk} . \\
\left.\text { ha }^{-1}\right)\end{array}$ & $\begin{array}{c}\text { Benefit } \\
\text { cost } \\
\text { ratio }\end{array}$ \\
\hline $\mathrm{T}_{1}: \mathrm{N}_{24} \mathrm{P}_{22} \mathrm{~K}_{42} \mathrm{~S}_{20} \mathrm{Zn}_{5}$ & 1.40 & $5,948 /-$ & $1,05,000 /-$ & $99,052 /-$ & $27,848 /-$ & 4.68 \\
$\mathrm{~T}_{2}: \mathrm{N}_{50} \mathrm{P}_{22} \mathrm{~K}_{42} \mathrm{~S}_{20} \mathrm{Zn}_{5}$ & 1.34 & $6,348 /-$ & $1,00,500 /-$ & $94,152 /-$ & $22,948 /-$ & 3.61 \\
$\mathrm{~T}_{3}: \mathrm{N}_{0} \mathrm{P}_{22} \mathrm{~K}_{42} \mathrm{~S}_{10} \mathrm{Zn}_{5}+$ Inoc. & 1.44 & $5,728 /-$ & $1,07,625 /-$ & $1,01,897 /-$ & $30,693 /-$ & 5.36 \\
$\mathrm{~T}_{4}: \mathrm{FP}\left(\mathrm{N}_{25} \mathrm{P}_{18} \mathrm{~K}_{21} \mathrm{~S}_{0} \mathrm{Zno}\right)$ & 0.99 & $2,671 /-$ & $73,875 /-$ & $71,204 /-$ & - & - \\
\hline
\end{tabular}

Urea = Tk. $7.00 \mathrm{~kg}^{-1}, \mathrm{TSP}=$ Tk. $17.00 \mathrm{~kg}^{-1}, \mathrm{MoP}=$ Tk. $18.00 \mathrm{~kg}^{-1}$, Gypsum= Tk. $8.00 \mathrm{~kg}^{-1}$, $\mathrm{ZnSO}_{4}=$ Tk. $95.00 \mathrm{~kg}^{-1}$, Rhizobium inoculum $=$ Tk. $100 \mathrm{~kg}^{-1}$, Lentil= Tk. $75.00 \mathrm{~kg}^{-1}$

For both the years, positive and significant correlation was found in nodule number with nodule weight (Table 3). Nodule number was strongly correlated with nodule weight. Nodule number was also correlated with root weight in 2007 and nodule weight was correlated with shoot weight and stover yield in 2008 (Table 3). Bhuiyan et al., (1996 and 2001) also reported positive and significant correlation for the inoculated chickpea. 
Table 3. Relationship between different parameters of lentil at Faridpur

\begin{tabular}{l|c|c}
\hline \multicolumn{1}{c}{ Parameters } & \multicolumn{2}{c}{ r values } \\
\cline { 2 - 3 } & 2007 & 2008 \\
\hline Nodule number vs nodule weight & $0.939^{* *}$ & $0.966^{* *}$ \\
Nodule number vs root weight & $0.618^{*}$ & $-0.207^{\mathrm{NS}}$ \\
Nodule number vs shoot weight & $0.581^{\mathrm{NS}}$ & $0.532^{\mathrm{NS}}$ \\
Nodule number vs stover yield & $-0.075^{\mathrm{NS}}$ & $0.412^{\mathrm{NS}}$ \\
Nodule number vs seed yield & $0.223^{\mathrm{NS}}$ & $0.386^{\mathrm{NS}}$ \\
Nodule weight vs shoot weight & $0.523^{\mathrm{NS}}$ & $0.647^{*}$ \\
Nodule weight vs stover yield & $0.048^{\mathrm{NS}}$ & $0.459^{\mathrm{NS}}$ \\
Nodule weight vs seed yield & $0.299^{\mathrm{NS}}$ & $0.400^{\mathrm{NS}}$ \\
Shoot weight vs stover yield & $-0.417^{\mathrm{NS}}$ & $0.670^{*}$ \\
Shoot weight vs seed yield & $-0.015^{\mathrm{NS}}$ & $0.091^{\mathrm{NS}}$ \\
Stover yield vs seed yield & $0.172^{\mathrm{NS}}$ & $0.050^{\mathrm{NS}}$ \\
\hline
\end{tabular}

"Significant at $5 \%$ level, ${ }^{* *}$ significant at $1 \%$ level, NS: Non-significant

\section{Conclusion}

It is evident from the experiment that biofertilizer can be used as the substitute of nitrogenous fertilizer in lentil at farmer's field in Faridpur district of Bangladesh.

\section{References}

BARC. 2005. Fertilizer Recommendation Guide-2005. Bangladesh Agricultural Research Council, Farmgate, New Airport Road, Dhaka-1205.

Bangladesh Bureau of Statistics (BBS). 2012. Statistical Yearbook of Bangladesh. 32nd Edition. Bangladesh Bureau of (BBS) Statistics. Ministry of Planning, Govt. People's Republic of Bangladesh. p. 133.

Bhuiyan, M. A. H. and D. Khanam. 1996. Nodulation and yield of chickpea- A field evaluation. Proc. $19^{\text {th }}$ Bangladesh Science Conference, Part-2. Pp. 163-166.

Bhuiyan, M. A. H., D. Khanam, A. Khatun, A. K. M. Hossain and M. S. Islam. 2001. Nodulation, dry matter weight and grain yield of chickpea as influenced by Rhizobium inoculation. Bangaldesh J. Agril. Res. 26(3): 463-466.

Bhuiyan, M. A. H., D. Khanam, A. K. M. Hossain and M. R. Khatun. 1996. Response of chickpea (Cicer arietinum L.) to Rhizobium inoculation in farmer's field. Bangladesh J. Crop Sci. 7(1\&2): 99-102.

Bhuiyan, M. A. H., M. S. Kabir and D. Khanam. 1998. Effects of boron, molybdenum and rhizobial inoculation on nodulation and yield of lentil. Bangladesh J. Seed Sci. Tech. 21(1\&2): 39-44.

Dube, N. N. 1976. Yield response of soybean, chickpea and lentil to inoculation with legume inoculants. In: Symbiotic Nitrogen Fixation in Plants. Nutman, P. S., ed. Cambridge University Press, Cambridge. Pp. 385-403.

Khanam, D., M. H. H. Rahman, M. A. H Bhuiyan, A. K. M. Hossain and A. F. M. Rahman. 1993. Effect of rhizobial inoculation and chemical fertilizer on the growth and yield of lentil at Two Agroecological zones of Bangladesh. Bangladesh J. Agril. Res. 18(2): 196-200.

Khanam, D., M. A. H. Bhuiyan, M. H. H. Rahman and A. K. M. Hossain. 1999. On-farm experience of the application and adoption of biological nitrogen fixation technology in Bangladesh. Bangladesh J. Agril. Res. 24(2): 375-382. 